\title{
Remembering the Lebanese Wars in Abbas El-Zein's Leave to Remain (2009)
}

\author{
Lahcen AIT IDIR \\ Sultan Moulay Slimane University, Morocco \\ aitidir.lahcenusms@gmail.com
}

DOI: https://doi.org/10.36892/ijlls.v2i4.467

Received:

29/11/2020

Accepted:

$26 / 12 / 2020$

Keywords:

Diaspora, Lebanon, memory, history, Justice, war crimes.

\section{Abstract}

Soon after the Civil War's end in 1990, the state in Lebanon has engaged in a discourse of amnesia, in a bid to proscribe any heed to the question of the war. The purpose is to conceal this dark chapter of the Lebanese history through the repression of memory. Through different practices of remembering, diaspora writers have tried, however, to offer alternative narratives of the Lebanese history. In so doing, they engage in resisting the official dominant ideologies through producing what Micheal Foucault would label as "insurrection of subjugated knowledges" (Foucault, p. 81). In studying Abbas El Zein's memoir Leave to Remain, this article sets out to explore how and in what ways post-war Lebanese Diaspora literature can be categorized as a form of history writing about war. This article focuses on the Civil War (1975-1990) and the July War in 2006.

\section{INTRODUCTION}

Subtitled a memoir, Abbas El-Zein's Leave to Remain narrates the story of El-Zein's journey traversing countries, starting from his youth life in Lebanon to other Arab and Western countries. As the title reveals, Leave to Remain is about the war-torn Lebanon, which urges for many "leavings" but warrants many "returns" as well. El-Zein's memoir consists of two parts, each of which is made up of many chapters. The first part "Origins and Departures" is mainly about the troubled Lebanon, hence the necessity for leaving and belonging elsewhere. The second part "Unhappy Returns" is an account of attempts to return and belong in the post-war Lebanon and elsewhere. Together, the two parts are about El-Zein's interpretation and/or translation of himself. In this, El-Zein (2009) employs what he calls three literary forms in his memoir writing, namely "fictional-type dramatization," "travel writing," and the “autobiographical essay" (p.1).

Like many other diasporic narratives, Leave to Remain participates in a discourse of resistance against the attempts of the Lebanese government to interrupt any talk about the civil conflict (Barak, 2007). As post-war narratives, they "play the role of adversary" (Foucault, 2003 , p. 96). They bring to the front different painful experiences and memories in order to excavate the massive destruction and crimes brought about by the war. In narrating these (hi) stories, Lebanese diaspora writers not only interrogate hegemonic discourses and put forward alternative ones, but they also do justice to the victims of the war (Shapiro, 2014). These victims were subjected to massive acts of violence, whose agents were granted amnesty as a way out to move beyond any more discussion of the Civil War. Nevertheless, the authors of 
diaspora are hyper-aware of the nefarious effects of these practices of forgetting. In fact, they strongly believe in remembering as a moral practice. In this regard, El-Zein (2009) writes:

Somewhere in my mind, I had assigned cruelty to the past, as if violence and injustice had disappeared when the war ended [...]. Was it not our moral imperative to remember those against whom violence was committed as we spoke, in the same way we felt the urge to erect memorials for those who have been killed yesterday? While local politics, almost by definition, would work against such remembrance, a city which could not mount a resistance against its own parochialisms was not worthy of the name. (p. 207)

During the 15-year conflict, Lebanon underwent massive destruction, and thousands of people died. Victims also included thousands of injured, missing and displaced people. Many others were victims of shell shock. To El Zein, it is a moral imperative to remember these victims. Remembering is a form of justice. It is also a way of resisting forgetting and the politics of amnesia sought by the state. Indeed, in the post-war period, the state and local politics strived for containing political/public memory, employing such policies as supporting operations of forgetfulness, silencing any debate about the war, as well as granting amnesty on all war crimes. The public discourse centered also on initiatives of reconciliation to hinder any attempts to discuss the war, its causes and its consequences. More than this, denying the past violence has been a strategy followed as a way out of the war.

Against all these endeavors, writers of diaspora, for example, believe it is necessary to look back and write about these traumatic memories. Worth noting here is the significance of literature in dismantling political agendas with regard to the devastating war. In this context, literature and politics are in tension, in that the former disrupts the second. The role of literature is therefore to correct history by offering other versions of the narratives of the past. In his book The Writer as Migrant, Ha Jin (2008) rightly pinpoints that

to preserve is the key function of literature, which, to combat historical amnesia, must be predicated on the autonomy and integrity of literary works inviolable by time [...] the writer should be not just a chronicler but also a shaper, an alchemist, of historical experiences. The writer should enter history mainly through the avenue of his art. If he serves a cause or a group or even a country, such a service must be a self-choice and not imposed by society. (p. 30)

In this sense, post-war Lebanese diaspora writing acts against historical amnesia through narrativising historical experiences and incidents. The writer stands as a voice with a cause, that is, to represent the past and erect memorials for victims of the massive shelling. Deemed artistic creations, diasporic works are not state-sponsored. They are self-choices; a quality that testifies to their reliability in projecting other versions of the past. It is true that most of these works are fictional, but there are instances where the boundaries between fiction/fact and story/history get blurred. Interestingly, as the generation of memory, most of the diaspora writers in English experienced the Civil War. This has enabled them to act and write as eyewitnesses of the war and its repercussions. Leave to Remain benefits much from the personal experiences of El-Zein during the war, as well as in the post-war period. In fact, his many departures from and many returns to Lebanon are stimulated by the war. This is what makes Leave to Remain a narrative about the war. In narrativising the war, El-Zein writes 
against the suppression of memories and the expression of official histories. This being the case, diasporic writing can be qualified as counter-history.

\section{Remembering the Civil War in Leave to Remain}

As mentioned earlier, El-Zein participates thus in opening a discussion about war atrocities and war destructions. In doing so, he captures images of people went missing as a result of gigantic gunfire. The memoir's use of the narrative voice "I" is not bereft of references to collective experiences. In fact, in trauma narratives, the personal trauma and the collective trauma intertwine, especially in moments of conflicts and wars. Writing one's trauma, as in the case of El-Zein, offers soulful insights into the collective trauma experienced by a whole generation of Lebanese people. By doing so, El-Zein "commemorates all those innocents whose abuse at the hands of war criminals has caused unending anguish" (Hout, 2012, p. 78). In this, El-Zein forges different explorations of traumatic events related to the massacres committed against civilians.

In narrativising different painful experiences, he focuses mainly on his family. In this vein, he cites his "uncle who scoured the south, despite ongoing danger, trying to find his mother. Finally, more than a week after she had gone missing, he identified parts of her bodydismembered and largely decayed the rubble of a house [...]- from the clothes she is wearing" (El-Zein, p. 56). The importance of El-Zein's memoir resides in conveying the callous reality of the war. As a survivor of the war, he can be said to prompt a discussion on questions related to crimes against people. In this sense, the function of memory is not about looking back to the past, but it is about passing these narratives to the public in order to challenge public amnesia. If memories tell us who we are, then the stories of El-Zein family are those of a generation that experienced the war. War-related identities projected in the context of protracted violent conflicts are meant to tap into the collective trauma of the Lebanese people. In so doing, the memoir is revelatory of post-war consciousness developed by writers in order to showcase the impact of war on individuals, families and countries. In fact, through the writer's "I", El-Zein's narrative serves as an autobiographical reflection on the past that is denied and silenced by the post-war government. In this autobiography, El-Zein sifts through personal memories of the past to explore the hazardous effects of war on the victims of the war. No wonder, the memoir is fraught with images of war-related traumatic experiences. The following excerpt strikingly indicates the huge impact of war crimes on its survivors. It captures his mother's exposure to extreme stress after the death of El-Zein's grandmother during a trip under the shelling and air raids. El-Zein (2009) writes:

This event took a heavy toll on my mother. When death was finally confirmed, she collapsed. She had had a trivial dispute with her mother a couple of weeks before the war, and never forgave herself for not making it up with her. I was fifteen at the time and what I remember most was my mother's shriek coming to a sudden end, her body abruptly surrendering to pain. It was as if she had to share some of her grief with us, draping it on the walls of our house, then keep the rest inside her, in a private pact with her mother. (p. 57)

This passage addresses an important element of the Lebanese's trauma, namely their inability to cope with the massive massacres brought about the war. It communicates experiences of pain as a result of loss of loved ones. El-Zein's narrative offers a space for traumatized people to share their experiences. In this sense, his memoir engages in trauma writing. It accounts for the nefarious effects of atrocities the protracted conflict has had on 
civilians. The grief endured by El-Zein's mother culminates in her "collapse", "surrender to pain" and suffering inside. In the same vein, this indicates the traumatic state of the diasporic subject himself, that is, El-Zein. In talking about the traumatic experiences of his countrymen, El-Zein offers expression of his own trauma as a survivor of the war. This is attained through the use of memory. This is best manifested in the verb "remember" used by El-Zein in the passage above to look back to a scene he lived in the past. Narratives of memory become thus the only space for communicating the past trauma. In other words, the traumatic memories are informed by narrative memories. In this manner, diasporic post-war narratives are informed by a past trauma that binds together the members of a group, which is the Lebanese people, in a victimizing discourse. The victims are offered a literary space through which to express their painful experiences. As a diasporic narrative exploring historical trauma and cultural displacement, Leave to Remain reflects different forms of personal and collective misery. One seemingly obvious explanation is the author's disdained interest in the reconstruction of wartime experiences to resist cultural amnesia implemented by the postwar government as a policy to silence any discussion about the war.

In exploring the trauma caused by the war, El-Zein stresses also the trauma of frequent displacement experienced by the migrants. In fact, it has been underlined how the Lebanese Civil War has contributed to massive dispersion of Lebanese across countries. The Lebanese diaspora has been shaped as a result of the national disintegration caused by the war. In his article "Lebanese Identities: Between Cities, Nations and Trans-Nations", Michael Humphrey (2004) notes that the "[Lebanese] diasporic experience is the product of national disintegration and the destruction of social worlds and their experience of resettlement in migration" (p. 32). In communicating different diasporic experiences, diasporic texts are loaded with allusions to the war as the main push factor behind the waves of immigration. This being the case, these texts are often labeled post-war narratives. They are narratives largely embedded in and informed by the war. In fact, the literature of the Lebanese diaspora is mainly shaped by the experience of war. Humphrey continues that "[W]hen diasporas have been created by displacement through state repression and war they often remain very active political constituencies with grievances against the state" (p. 34). The post-war Lebanese diaspora narratives can be inscribed within this framework. Its producers are active agents with a postwar consciousness to write back to the state and dismantle official histories that sought to deny past violence. With this objective in mind, diasporic writers continue to write about the war and provide different images of corrosive effects of the war. The excerpt below testifies to the gigantic displacement experienced by different families as a result of the war. Victims have moved across places, cities, and countries in search of safety and flee the dire situation they live in:

During the civil war, from 1975 to 1990, many families move from one place to another, one city to another, as the war ebbed and flowed. The war, like a mad fairy, kept shifting location and changing intensity; there were times when it appeared to have expired, only to re-erupt a year or two later [...]. To be burnt or torn to pieces by a shell or an air-to-ground missile was no more pleasant a prospect than to be impaled on a pointed stake. (p. 85)

Following clashes in Beirut, thousands of civilians fled to different destinations inside and outside Lebanon. It is shown here how the traumatic dispersal is involuntary; departure is deemed necessary in war-torn sites. The passage accounts for Horrors of the war. The metaphor "mad fairy" is revelatory of the huge source of threat. In foregrounding families through a discourse of victimhood, El-Zein is keen on providing a mental picture for the reader about the 
Lebanese collective experience. This experience is dramatic, in that a large part of the Lebanese population was forced to escape the country. Writing about these collective experiences is meant to form a collective memory (Halbawchs, 1992) functioning as an archive of acts of violence against civilians. In this sense, El-Zein engages in what is previously discussed as "literary justice". It is a way of doing justice to the victims by telling their stories and keeping them alive. These versions of stories produce different histories that disrupt the state's policy of cultural amnesia. They also challenge the state's aim to limit access to memory by opting for specific narratives in order to control the public discussion and space. In his book The Politics of Atrocity and Reconciliation, Michael Humphrey (2004) writes that, based on Marcus' argument (1994), "the bureaucratic archiving of memory preserves the state and limits access to other kinds of remembering, restricting them to private memory. These may simply be deferred until a time when the political climate is more receptive, when the truth is more digestible" (p. 115). While the state poses more restrictions to remembering through a process of forgetting, narratives of post-war diasporic literature disrupt these policies. To these narratives, acknowledging the past violence, hence telling the truth, is essential to the process of reconciliation. Writing these crimes and traumas is a moral practice. It is a form of justice to the victims through the diasporic voices, as survivors of the war. It also offers soulful insights into lessons of history. In this manner, El-Zein's memoir shows much affinity to Jarrar's novel, in that both participate in war discussion, and they strive to provide alternative versions of the past. In doing so, they are storages of new insights into the Lebanese history of war and its corrosive ramifications on thousands of people.

It is also interesting to note how the two texts tap into the intervention of Israel as an agent in the Lebanese Civil War. In this context, the issue of Palestinians refugees in Lebanon has been brought to the fore to account for the war crimes committed against civilians. Likewise, El-Zein's memoir heeds attention to the presence of Israel in Lebanon. In so doing, a number of acts of violence by Israel are highlighted. In this way, El-Zein's memoir can be seen as a reflection on the whole region of the Middle East in its relation to the West and Israel. The American and Israeli long-standing presence in the Middle East and its affairs, particularly Lebanon, make them subject to discussion in different creative works. In fact, different diasporic texts have thrown light on this relationship, focusing on different moments of encounters and conflicts. El-Zein's memoir is no exception. For instance, the crimes committed during the Lebanese conflict are deemed drastic. An example El-Zein explores is that the mass murder done in the camps of Sabra and Shatila where thousands of Palestinian refugees were killed and others were injured. The attacks took place in September 1982 after Israel's invasion of the country. It is a refugee camp massacre that brought about mass graves. Writing about this war crime, El-Zein informs us that

Scores of Palestinian civilians were killed by Christian militiamen brought into the camps of Sabra and Shatila by the Israeli army; Israeli soldiers were shot point-blank on the streets of West Beirut by the incipient Lebanese resistance, before the Israeli army pulled out in a haste a few days after entering the city [...] The new regime set up by the Israelis and the Americans would collapse two years later; eighteen thousand Lebanese and Palestinian civilians- more than half a per cent of the total population- would be killed during the Israeli invasion. (p. 98)

No wonder, memoirs, such as that of El-Zein, is an interpretation of oneself, in that it presents an account of the experiences that its creators have gone through. Memoirs are reflections of individual consciousness. Interestingly, historical events are lived collectively, their impact is 
collective, and they contribute to the making of collective memories. In El-Zein's memoir, the individual and the collective come together. It is through the individual voice of the writer that the collective experiences are constructed. It therefore plays a major role in the formation of a collective consciousness upon which the identity of the group is based. This manifests itself ostensibly in the narration of the collective trauma. Throughout the memoir, El-Zein alludes to different historical events that led to the killing of innocent civilians. What is more, the memoir is also preoccupied with the question of Palestine, given the intricate relationship existing with Lebanon in the troubled region of the Middle East. Worthy of mentioning is the presence of Palestinian refugees in Lebanon since the "Nakba" when thousands of Palestinians fled or were forced out of their homes during the 1948 Palestine war. Lebanon was one of the destinations.

Palestinians were not only expelled from their homes, but they also were victims of mass shelling elsewhere. The Sabra and Shatila massacre pointed out in previous passage is a case in point. The parties of the massacre included the Lebanese army, the Christian militiamen and the Israeli army. They shelled the camps causing the death of thousands of people including children, women and old men. Houses were also destroyed and camps were damaged. In fact, the Israeli intervention in Lebanon is to weaken the Palestinian movement and to set up a Lebanese regime with the Americans to serve the interests of Israel in the region. This being the case, thousands of Palestinians were dead, and the infrastructure was massively destroyed. Unsurprisingly, the attacks worsened the situation of thousands of stateless Palestinians across the region and elsewhere.

Trying to make sense of what happened is at center of El-Zein's memoir. Writing about Sabra and Shatila is meant to bring back to the fore the forgotten attacks. It is a reminder of the traumatic experience of Palestinians, and it shows Israel's responsibility in Lebanon. This writing shapes the collective memory of both Palestinian and Lebanese people. In this manner, Leave to Remain can be seen as a testimonial narrative reflecting on the atrocities committed by external actors in Lebanon, mainly Israel with the support of the Americans. It is a commemorative creative work resisting forgetfulness aimed at by hegemonic discourses, and it is a call for remembering the casualties in order to do justice to them. In this sense, equity and reconciliation can be achieved not by limiting access to public memory and controlling the public space. Rather, remembering is essential for any future conciliatory projects. El-Zein's text is politically in opposition to official discourses to deny past violence. Exploring the Civil War and its repercussions as well as the intervention of Israel is the impulse of El-Zein's commemorative discourses. At heart of his text is also the very recent history of Lebanon, particularly the 2006 July war between Lebanon and Israel.

\section{Writing the 2006 July War}

The history of Lebanon is a complex one, owing to its repetitions. The recent history bears affinities to the past history, particularly the protracted Civil War1975-1990, in that Lebanon witnessed a huge number of casualties and massive destruction of buildings and infrastructure. It has been underlined how diaspora narratives have sought to challenge cultural amnesia by writing about the war. These narratives offer different perspectives on the traumatic collective experiences that the Lebanese went through. In writing about the war, these writers disrupt hegemonic discourses attempting to silence the discussion about the civil strife. Hence, their practices are seen as moral in recognition of the victims of the war, and as a preliminary step towards equity and reconciliation. Having not yet achieved these aims and forgotten the painful past, the Lebanese people were shuddered by a new war. 16 years after the end of the horrible Civil War, the 2006 July war brought similar images of the past in terms of fatalities and destructions. It is interesting how El-Zein's memoir captures not only images of war-torn homeland during the Civil War but also images of the July War. In this sense, his memoir is a 
reflection on the different drastic experiences that the Lebanese lived through. It is as if ElZein is keen on exploring repetitions of history that are caused by, inter alia, ignoring the past, hence ignoring learning from it. During this war, which was mainly between Hezbollah and Israel, thousands of civilians died, thousands were injured and around one million displaced. Narrativising this conflict, El-Zein taps into its corrosive effects on civilians, and he seeks to engage in a process of memory writing about the recent past. Contextualizing the July War, ElZein writes that

Over the month following the capture of the two soldiers, the Israeli air force launched deadly air raids on a largely defenceless country, targeting power plants and bridges right across the land and whole neighborhoods, killing over a thousand civilians in four weeks- a third of whom were children- displacing close to a million people littering the south of Lebanon with yet-to-explode cluster bombs. Hezbollah responded by bombing the north of Israel, including the city of Haifa, targeting both military and residential areas of the city. More than a hundred Israelis died, a third of whom were civilians. (p. 251)

Writing in retrospect, El-Zein's depictions unfold what seems to be like repetitions of history. The 2006 July War is portrayed as an extension of the 1975-1990 civil conflict. During the thirty-three days of the 2006 summer attacks, thousands of people died, and around one million displaced. Gruesome images of victims are reminiscent of those lived by the generation of the Civil War. In fact, the lines between the past history and its present appear blurry. In her article "Writing Memories of the Present: Alternative Narratives about the 2006 Israeli War on Lebanon", Carol N. Fadda-Conrey (2010) writes that "the difference between days and weeks become more and more blurred. Slowly, with the tendency of history to repeat itself, the past and the present also merge, so much so that, for the generation that is old enough to remember, the siege of 2006 becomes one and the same as the 1982, 1993, and 1996 Israeli incursions into Lebanon" (p.168). Strikingly, Lebanon has been a target of different invasions. Every attack leads to many fatalities. After the attacks in the camps of Sabra and Shatila, a set of wars were launched against Lebanon, targeting both the Palestinians and the Lebanese.

This said, El-Zein's memoir is not only embedded in the Civil War stories, but it also proposes a space for the stories of those who experienced trauma during the July War. These stories are told from the vantage of diaspora. In this context, El-Zein shows how he followed the events from Sydney through "Internet, newspapers, emails, and telephone calls to friends and family" (p. 252). In fact, different virtual means of communication are largely at work in order to relay the atrocities worldwide. However, reporting has not been without problems, owing to the resistance displayed by pro-Israeli and Western media to disrupt stories about the war. El-Zein unfolds his predicament attempting to check the news about the bombardments that Lebanon witnesses. In writing about the July War, El-Zein could present images of families died and displaced. His autobiographical "I" shifts from the personal to include the collective. In this sense, Leave to Remain could be said to engage in narrating a common national traumatic experience through the "eye"/ "I" of El-Zein. In telling his own story, El-Zein is presenting an account of the stories of others.

As a survivor of the war, El-Zein strives to keep the collective experience alive. It is a way to resist the attempt to bury the crimes committed in the land of Lebanon against civilians. This could be read as an attempt to avoid repeating the mistakes of the past, particularly public amnesia about the war. El-Zein's memoir offers a war narrative of the July war in order to disrupt obliteration from the collective memory as it is the case of the Civil War. More than 
this, the narrative is a challenge to the one-sided historicity of the war, either by the Lebanese state or by Israel and its pro-western narratives. Narrativising the war is, as stated earlier, a form of justice for victims of war crimes in Lebanon. El-Zein's memoir is a war-testimonial contributing largely to a "historical and cultural consciousness" against cultural amnesia that is embedded in burying the memory of the war. El-Zein's memoir can be best described as "living archive", in Fadda-Conrey's words, for the war. This archive is formed by war testimonials which, as is the case of El-Zein,

By delivering a multi-layered portrayal of this region and its people through a first-person perspective, [they] break the unilateral and onesided depiction of Arab identity and culture as disseminated through Western media. Establishing such a personal, and by extension, collective record of war experiences becomes the first step toward connecting with a country's history and people, so as to keep the significance and implications of this history alive, no matter how traumatic or scarring it might be. (Fadda-Conrey, 2010, p. 170)

As a war testimonial, El-Zein's memoir seeks to preserve history in the memory of people (Ricoeur, 1996). This is done through offering a record of different war experiences, be they personal or collective. The one-sided historicity of the war is therefore challenged and disrupted. In fact, El-Zein showcases many experiences of himself, his family, and other Lebanese civilians in order to keep an archive of the war. This is a way of constructing an authentic record as a window to the past. In this sense, his narrative is a repository of memory. In keeping the memory of the past, the identity of the nation is always preserved. The purpose is to combat memory distortion, especially when recording the seminal events of July War. Worth mentioning, as Fadda-Conrey pinpoints, is the biased western representation of the Arab identity during its coverage of the July War. In her same study (2010), Fadda-Conrey delves into the dichotomous representation of the Arabs, particularly since after 9/11. In the war of 2006, the western mainstream media provided negative images about the Lebanese Arabs. In doing so, they sought to write single versions of the war. However, there were many counternarratives made viable through cyber logs, online journals, and news outlets documenting the massacres in Lebanon. Indeed, these narratives have provided storage for history (re)writing and 'archive' construction. They provided alternative stories about the experiences of the war, challenging thus the Western media representation and its implications.

\section{CONCLUDING REMARKS}

Employing different narrative tools, El-Zein offers different perspectives about the Civil War and the July War in Lebanon. According to him, it is a moral practice to write the war in order to account for the crimes committed against civilians by the militiamen and by foreign interventions. In doing so, El-Zein's memoir hinges on a plethora of personal and collective experiences meant to archive the war and preserve its memory against attempts at political amnesia. The aim is, inter alia, to do just to the victims by (re)writing the history of the war, hence a way to learn from the lessons of the past to avoid the repetitions of history. This has been presented through different images, articulating the impact of wars on individuals, families and places. 


\section{REFERENCES}

Barak, O. (2007). "Don't Mention the War?" The Politics of Remembrance and Forgetfulness in Postwar Lebanon. The Middle East Journal, 61(1), 49-70.

El-Zein, A. (2002). "Being elsewhere: on longing and belonging". Arab-Australians Today, 225- 240.

-(2009). Leave to Remain: A Memoir. UQP.

(2009). "Interpreting oneself: on memoirs, essays, fiction and travel writing". In Talk at Macquarie University English Department Seminars Series, May (Vol. 11).

Fadda-Conrey, C. N. (2010). "Writing memories of the present: Alternative narratives about the 2006 Israeli War on Lebanon”. College Literature, 159-173.

Foucault, M., \& Ewald, F. (2003). " Society Must Be Defended": Lectures at the Collège de France, 1975-1976 (Vol. 1). Macmillan.

(1990). The History of Sexuality: An introduction, volume I. Trans. Robert Hurley. Vintage.

Halbwachs, M. (1992). On collective Memory. University of Chicago Press.

Hout, S. (2012). Post-War Anglophone Lebanese Fiction: Home Matters in the Diaspora: Home Matters in the Diaspora. Edinburgh University Press.

Humphrey, M. (2004). "Lebanese Identities: Between Cities, Nations and Transnations". Arab Studies Quarterly,31-50.

(2013). The Politics of Atrocity and Reconciliation: From Terror to Trauma. Routledge.

Jin, Ha. (2008). The Writer as Migrant. The University of Chicago Press.

Marcus, G. E. (1994). The Official Story: Response to Julie Taylor. In Body Politics (pp. 204-208). Routledge.

Ricoeur, P. (1996). Memory, Forgetfulness, and History. Iyyun: The Jerusalem Philosophical Quarterly/13-24, עיון :רבעון פילוסופי.

Shapiro, M. J. (2014). War Crimes, Atrocity and Justice. John Wiley \& Sons 


\section{AUTHOR'S BIO}

Lahcen Ait Idir is a teacher of English in Preparatory Classes in Beni Mellal, Morocco. He is also a Ph.D researcher in the Ph.D program "Interactions in Literature, Culture and Society" affiliated to Sultan Moulay Slimane University, Morocco. His research activities include interventions, in national and international conferences, and publications in cultural studies. His research interests focus on postcolonialism, diaspora studies, and language teaching. 